\title{
Supplements to the Enumeratio Plantarum Formosanarum.
}

\author{
By \\ B. Hayata \\ Assistant in the Botanical Institute, Science College, \\ Imperial University, Tokyo. \\ (Continued from p. 15.)
}

Last year I continued my writing in this magazine under the title of "Contribution to the Flora of Mt. Morrison"; and also wrote a few times under the title of "Supplements to the Enumeratio Plantarum Formosanarum." I think now it would be better to combine the former with the latter, as both subjects are in the same field of investigation. In this paper, therefore, I shall try to give all my study to the botany of any region of the Island of Formosa.

Arundinaria niitakayamensis Hayata, sp. nov. Culmus foliifer $50-60 \mathrm{~cm}$. longus, suffruticosus, ramis glabris, ramosis, fasciculatis, inæqualibus, internodiis $5 \mathrm{~cm}$. longis; folia lanceolata, $4 \frac{1}{2} \mathrm{~cm}$. longa, $5-6 \mathrm{~mm}$. lata, apice acuminata, basi in petiolum brevem attenuata, margine scabra, nervis secundariis utraque latere $2-3$, venulis transversis numerosis tessellata, subtus pallidiora, glabra; vaginæ striatæ $2 \mathrm{~cm}$. longæ, apice ciliis paucis longis, ligulis $\frac{1}{2} \mathrm{~mm}$. longis acutis. Culmus florifer $40-50 \mathrm{~cm}$. longus, simplex, internodiis $5-6 \mathrm{~cm}$. longis; folia lanceolata $10 \mathrm{~cm}$. longa, $1 \mathrm{~cm}$. lata, acuminatissima, supra glabra subtus pauce hirsuta; vaginæ $8-9 \mathrm{~cm}$. longæ, pallidopurpurascentes, ligulis conspicuis, $2 \mathrm{~mm}$. longis, extus hirsutis. Panicula laxe racemosa $15 \mathrm{~cm}$. longa. Spiculæ $3-4 \mathrm{~cm}$. longæ, subcylindraceæ, 3-7floræ, rhachillis articulatis hirsutis, longe pedicellatæ. Glumæ I. et II. inæquales lanceolatæ, gl. III. brevior; gl. [I.] 5-nervis, nervis inconspicuis, $7 \mathrm{~mm}$. longa, subulata, $2 \mathrm{~mm}$. lata; gl. II. longior ovato-oblonga 7-nervis, nervis inconspicuis, $8-9 \mathrm{~mm}$. longa, $3-4 \mathrm{~mm}$. lata, sub lente scabero- 
hirsutiuscula; gl. III. 9-nervis, nervis conspicuis, ovato-acuminata, $14 \mathrm{~mm}$. longa, $5 \mathrm{~mm}$. lata, fusco-purpurascens, margine glabra. Palea pauce brevior, depressa, apice bimucronata, bicarinata, carinis obscure ciliatis. Lodiculæ 3, longæ, obovatæ, ciliatæ, nervosæ. Stylus 2-fidus; ovarium oblongum in stylum attenuatum.

Hab. in monte Morrison, Ganzan, ad 9141 ped. alt., leg. S. Nagasawa, Nov. anno 1905, (No. 678).

Eremochloa ophiuroides Hack. Mon. Androp. p. 261; ForBes et Hemsl. Ind. F1. Sin. III. p. 363.

Ischæmum ophiuroides Munro; Benth. Fl. Hongk p. 425. Hab. Kinpori, leg. G. Nakahara, Jun. anno 1905, (No. 87); Shakkō, leg. S. NAGaSAwa, anno 1905.

Distrib. South China.

Oplismenus undulatifolius Beauv. var. imbecillis Hack.; Merrill, in Philip. Journ. Sci. I. Suppl. pp. 28 et 364.

Panicum imbecille 'Trin. Ic. Gram. t. 191.

Hab. Taiton, leg. Z. Kobayashi, anno 1905.

Thuarea sarmentosa Pers.; Benth. Fl. Hongk. p. 415; Hook. f. Fl. Brit. Ind. VII. p. 91; Makino, in Tōkyō Bot. Mag. IX. p. 256 ; Hack. in Bul. Herb. Boiss. (1899). p. 722 ; Forbes et Hemsl. Ind. F1. Sin. III. p. 340; Matsum. et Hayata, Enum. P1. Formos. p. 512.

Ornithocephalochloa arenicola Kurz, in Journ. Bot. XIII. (1875) p. 332, t. 171.

Hab. Köshiryō, leg. G. Nakahara, anno 1905, (No. 172); Taitō: Shinkōgai, leg. T. Kawakami et Z. Kobayashi, anno 1906, (No. 1514 et 1533)

Distrib. Ceylon, Cochinchina, Malay, North Australia, Pacific Islands, Loo-choo and South China; but not hitherto known from Formosa. 


\section{Deschampsia sp.}

Hab. in verticem montis Morrison, ad 13094 ped. alt.; leg. S. Nagasawa, Nov. anno 1905.

This specimen was collected too late in the season and there remained but a few empty glumes. But in its general appearance, its leaves and ligules, it may be a near species of Deschampsia flexuosa or even the same species.

Brachypodium Kawakamii Hayata, sp. nov. Perennia erecta subcaespitosa, circ. $20 \mathrm{~cm}$. alta. Folia convoluto teretia, laminis $5-6 \mathrm{~cm}$. longis, utraque latere $6-7$-nervis, extus glaberrima sed intus scabra pauce hirsuta, vaginis $2 \mathrm{~cm}$. longis, ligulis latioribus brevibus leviter ciliolatis. Spiculæ paucæ saepe ad unam terminale $n$ reductæ, pedunculis tenuissimis, 67-floræ, compressæ $2 \mathrm{~cm}$. longæ, $3 \mathrm{~mm}$. latæ, rhachillis inter flores articulatis hirsutissimis; floribus hermaphroditis sed superioribus imperfectis. Glumæ 2 inferiores vacuæ, 7-nervis, florentibus minores et breviores muticæ, subglabræ; gl. [I.] 7-mm. longa; gl. II. longior; gl. florens rigidula, angusta, dorso rotundata, 7-9-nervis, integra, in arista $\mathrm{m}$ recta $\mathrm{m} 4 \mathrm{~mm}$. longam desidens; palea gluma vix brevior $7 \mathrm{~mm}$. longa, latiuscula, 2-carinata, carinis ciliatis, apice truncata et emarginata. Stamina 3. Ovarium apice appendiculo brevi villoso coronatum; styli longiusculi, stigmatibus laxe plumosis. Caryopsis anguste oblonga a dorso compressa antice late sulcata palea adhærens.

Hab. in verticem montis Morrison, leg. T. Kawakami et G. Nakahara ; et ad 13094 ped. alt., leg. S. Nagasawa, Nov. anno 1905, (No. 615).

Smallest form of Brachypodium, remarkable for its terete leaves, and its simplest form of a spike reduced into one spicule at the end of a very slender peduncle. Leaf very slender and it measures but $1 \mathrm{~mm}$. in diameter, and $3 \mathrm{~mm}$. in circumference.

Festuca ovina Linn. MiQ. Prol. p. 170 (typica); Franch. et Sava'T. Enum. P1. Jap. II. p. 181; Thome, F1. Deutschl. I. p. 114, t. 53, A; Wagner, F1. Deutsch. p. 82 ; var. vulgaris косн; Hack. in Bull. Herb. Boiss. VII. (1899) p. 713 et Ser. 2, II. (1903) p. 506. 
Hab. in verticem montis Morrison, ad 13094 ped. alt., leg. S. Nagasawa, Nov. 1905, (No. 598).

Distrib. Europe, North China and Japan.

This is the only species of Festuca found in this interesting mountain. Although the specimen is in too late a stage of blossoming to show a perfect flower, I have no hisitation in identifying it with Festuca ovina on account of its great resemblance in the form of foliage, flowerless glumes and its habits. This grass is common on high elevations in Japan, and ranges over the Kurile Islands in the north and southwards to central Japan. It is rather a remarkable matter that we have found this species on a high elevation in the Island of Formosa.

Panicum sarmentosum Roxв. F1. Ind. I. p. 308; Benth. F1. Hongk. p. 412; Hance, in Journ. Linn. Soc. XIII. p. 133; Hook. f. F1. Brit. Ind. VII. p. 54 ; Forbes et Hemsl. Ind. F1. Sin. III. p. 333 ; MerrilL, in Philipp. Journ. Scienc. I. Suppl. pp. 27 et 360 .

Panicum concinnum Nees; Steud. Syn. Gram. p. 78.

Panicum incomtum Trin. Ic. Gram. t. 232.

Panicum micrognostum Steud. Syn. Gram. p. 78.

Panicum vacillans STEUd. 1. c. p. 75.

Hab. Rokukiri (Banchoryō), leg. G. Nakahara, Oct. anno 1905, (No. 588); Goshizan (Shintiku), leg. T. Kawakami, Dec. anno 1906, (No. 1289).

Distrib. India, Malay, Philippine Islands and Borneo.

In my specimens, I find two forms of this species; one having a rather contracted panicle, while the other has a spreading and more expanding panicle. This difference is due, I think, to the stage of the developement of the panicle. In the advancing stage, the panicle tends to expand its branchlets, though it is not so in its younger stage.

Agrostis Clarkei Hook. f. F1. Brit. Ind. VII. p. 257.

Hab. in verticem montis Morrison, leg. T. Kawakami et G. Nakahara, Nov. anno 1905. 
Distrib. Western Himalaya at an altitude of $2100 \mathrm{~m}$.

This Agrosts is very like $A$. canina of the northern part of Japan. But my Morrison specimen has no awn and of course it must be different from $A$. canina. Besides, in my specimen, glume I. and II. are narrow and more acuminate and gl. III. is much shorter. Hooker's description of A. Clarkei quite agrees with my plant.

Eragrostis formosana Hayata, sp. nov. Annua; culmi caespitosi $50-60 \mathrm{~cm}$. alti, internodiis $9-6 \mathrm{~cm}$. longis. Folia radicalia vaginis $4 \mathrm{~cm}$. longis ore pauce ciliatis, ligulis brevissimis ad orem vaginarum annulum formantibus, laminis linearibus, filiformibus, $10 \mathrm{~cm}$. longis, $2-3 \mathrm{~mm}$. latis basi pauce hirsutis. Panicula laxe effusa, $10-15 \mathrm{~cm}$. longa, $4-5 \mathrm{~cm}$. lata, ramis alternis. Spiculæ ovatæ in peripherio, $4-5 \mathrm{~mm}$. longæ, $2 \mathrm{~mm}$. latæ, $15-20$ floræ, pedicellatæ, pedicellis $1-\frac{1}{2} \mathrm{~cm}$. longis, rhachillis inter flores continuis glabris, floribus hermaphroditis. Glumæ 2 inferiores vacuæ, inæquales, florentibus breviores, carinatæ, 1-nervatae, dorso secus nervam minute denticulatæ; florens membranacea carinata, 3-nervis, nervis glabris, globosa, acuta, integra; palea gluma brevior, prominenter 2 -carinata, carinis alatis, alis minute dentatis, in gluma inclusa. Stamina 2. Styli distincti, longi, stigmatibus plumosis. Caryopsis globosa.

Hab. Nankōkei, leg. G. Nakahara, Aug. anno 1905, (No. 208). This new species much resembles $E$. unioloides in the form of its spikelets, but differs from it by the longer and more branched panicle, and still more by the filiformed leaf.

Spodiopogon tainanensis Hayata, sp. nov. Culmi elati, erecti, teretes, $2 \mathrm{~mm}$. in diametro aequantes in partibus superioribus. Folia caulina latiuscula plana, vaginis glabris margine ciliatis coriaceomembranaceis $7 \mathrm{~cm}$. longis oribus longe ciliatis, cilis $3 \mathrm{~mm}$. longis, ligulis brevibus glabris $1 \mathrm{~mm}$. longis v. longioribus, margine ciliatis, laminis $10-12 \mathrm{~cm}$. longis lanceolato-angustatis, acuminatis, planis, utraque pagina glabris, utraque latere 5-nervis, margine minute serrulatis. Panicula laxa longe pedunculata, conica, $10 \mathrm{~cm}$. longa, $3-4 \mathrm{~cm}$. lata, ramis ad nodos $2-3-$ 
fasciculatis, flexuosis ascendento-patulis, ad nodum infimum usque ad $5 \mathrm{~cm}$. longis in parte inferiori nudis, superne breviter ramulosis et remote spiculiferis. Spiculæ ad apices ramulorum paniculæ et laterales sæpissime ternæ, una sessili ceterae stipitatae, stipitibus inæqualibus mollis, floribus omnibus hermaphroditis. Glumæ 4, 2-exteriores vacuæ, tenuiter membranaceæ, oblongæ, extus longe barbatae, apice obtusæ ciliatæ; g1. I. $3 \mathrm{~mm}$. longa $2 \mathrm{~mm}$. lata, 8 -nervis; gl. II. $3 \mathrm{~mm}$. longa v. longior 8 -nervis, nervis inconspicuis; gl. III. hyalina minor $3 \mathrm{~mm}$. longa v.brevior, 2-nervis, paleam sæpeque in spicula sessili florem $\uparrow$ fovens; gl. IV. hyalina, apice $2-$ fida $2 \mathrm{~mm}$. longa, arista intra lobos $8 \mathrm{~mm}$. longa geniculata, palea tenuissima flore $\Varangle \mathrm{v}$. abortu $q$. Stamina 3. Styli distincti, stigmatibus plumosis.

Hab. Tainan leg. G. Nakahara, Oct. anno 1905.

This species resembles $S$. depauperatus, but differs from it by the shorter spikelet and long ciliated glume. The arrangement of flowers in the spikelet is rather variable in the species. In the sessile spikelet, g1. I. and II. are always empty, gl. III. has a male flower, and g1. IV. has a perfect flower. This arrangement of flowers is generally kept in the sessile as well as pedicelled spikelet. But sometimes, in a pedicelled spikelet, the perfect flower is reduced to a female one or more often to no flower at all.

Spodiopogon Kawakamii Hayata, sp. nov. Culmi elati, erecti, $1 \frac{1}{2} \mathrm{~m}$. alti, validi, $5 \mathrm{~mm}$. in diametro æquantes, subcompressi, in partibus inferioribus unilateraliter sulcati. Folia latiuscula plana, vaginis glabris membranaceis ad internodium applicatis, $20-30 \mathrm{~cm}$. longis, oribus extime ciliatis callosis, ligulis brevibus, glabris, $4 \mathrm{~mm}$. longis, laminis angustis lanceolatis acutis $50 \mathrm{~cm}$. longis $1.7 \mathrm{~cm}$. latis, supra glabris subtus hirsutis apice acutissimis basi longe attenuatis et petiolum bialatum usque ad $10 \mathrm{~cm}$. longum attenuatis, nervis utraque latere 6-7. Panicula oblonga, $23 \mathrm{~cm}$. longa, $5 \mathrm{~cm}$. lata, longe pedunculata, ramis ad nodos multo fasciculatis flexuosis ascendento-patulis, ad nodum infimum usque ad $10 \mathrm{~cm}$. longis, in parte inferiore nudis 
superiore breviter ramulosis et densius spiculiferis. Spiculæ $4 \mathrm{~mm}$. longæ, pilosæ, sæpissime pedicellatæ, pedicellis glabris, inæqualibus, spicula sæpius brevioribus. Glumæ4,2-exteriores vacuæ, tenuiter membranaceæ, longe ciliatæ, subæquales muticæ; g1. I. ovata $3 \frac{1}{2} \mathrm{~mm}$. longa leviter mucronata extus hirsuta intus glabra 12nervata; gl. II. 10-nervata leviter mucronata; g1. III. multo parvior, hyalina, margine ciliolata; gl. IV. oblonga, hyalina $2 \frac{1}{2} \mathrm{~mm}$. longa, apice bifida, arista $8 \mathrm{~mm}$. longa exerta. Caryopsis ovoidea $2 \frac{1}{2} \mathrm{~mm}$. longa, $1 \frac{1}{2} \mathrm{~mm}$. lata.

Hab. Kōshūn, leg. T. KawaKamı, anno 1905.

This new grass somewhat, resembles $S$. sibiricus, but is easily distinguished by its shorter and more densely arranged spicules towards the end of the branchlet, and still more by its pedicelled spicules. Moreover, in this new plant, the base of the spicule is somewhat bare and there is nothing like clustered hairs as is the case with $S$. sibiticus. This species also bears some resemblance to $S$. formosanus, but differs from it by the long awned glume and hirsute leaves.

Trisetum subspicatum Beauv.; Steud. Syn. Gram. p. 225; Hack. in Bull. Herb. Boiss. VII. (1899) p. 703; Forbes et Hemsl. Ind. F1. Sin. III. p. 400; Kawakami, in Tōkyō, Bot Mag. XIV. p. 112; Avena subspicata CLAIRv.; Hook. f. Fl. Brit Ind. VII. p. 278 ; Thome, Fl. Deutsch. I. p. 145.

Hab. in verticem montis Morrison, ad 13094 ped. alt.; leg. T. Kawakam et G. Nakahara; et S. Nagasawa, Nov. anno 1905, (No. 612).

Distrib. Kurile, Himalayas, and generally found in alpine and frigid regions.

Alopecurus agrestis Linn. Sp. P1. ed-2, p. 89; STeud. Syn. Gram. p. 149; Benth. F1. Hongk. p. 407; Hook f. F1. Brit. Ind. VII. p. 239 ; Ledeb. F1. Ross. IV. p. 465 ; Forbes et HemsL. Ind. F1. Sin. III. p. 385.

Hab. Taihoku, leg. S.Yano, anno 1897, (No. 511).

Distrib. Europe and western and northern Asia and India. 